\title{
MEMBINCANG ULANG KOMENTAR NABI TENTANG WILĀYAT AL-MAR'AH
}

\author{
Abdul Wahab \\ Fakultas Dakwah dan Komunikasi UNISNU Jepara \\ Jl. Taman Siswa (Pekeng) Tahunan Jepara \\ muslimin@unisnu.ac.id
}

\begin{abstract}
The study of wilayat al-mar'ah is interesting to be explored given the many rigid interpretations of the hadith of the Prophet so as to imply discredit the ability of women. Through the language and historical analysis of the hadith of the prophet concerning wilayyat al-mar'ah it is found that: a) in the language perspective, the hadith about wilàyat al-mar'ah can be interpreted that until whenever a people (wherever) will not succeed or prosper when handed over their (power) affairs to women (anywhere) to play a central role; b) The Prophet's comment on "women" let alone his power, for the writer can not be separated also by the condition of society that is "patriarchal". So for the sake of prosperity and "comfort" together, the tradition of male leadership must be preserved for a society which, during its history, positioned men as "rulers"; and c) the contextualisation of this study that the Apostle's commentary was not in terms of discrediting women, but in the context of his "pique" of Kisra's humiliation. Thus, this hadith can not be understood rigidly, even though its editorial "insults" and "cursing".
\end{abstract}

Keywords: wilayyat al-mar'ah, Hadith of the Prophet 


\begin{abstract}
Abstrak
Kajian wilāyat al-mar'ah menarik untuk ditelusuri mengingat banyak penafsiran kaku terhadap hadist nabi sehingga terkesan mendiskreditkan kemampuan perempuan. Melalui analisa secara bahasa dan historis terhadap hadist nabi tentang wiläyat almar'ah ditemukan bahwa: a) dalam prespektif bahasa, hadits mengenai wilāyāt almar'ah dapat dimaknai bahwa sampai kapanpun suatu kaum (di manapun) tidak akan sukses atau beruntung apabila menyerahkan urusan (kekuasaan) mereka kepada perempuan (mana saja) untuk menjalankan peran sentral; b) Komentar Nabi terhadap "perempuan" apalagi kekuasaannya, bagi penulis tidak terlepas pula dengan kondisi masyarakat yang memang "patriarkhis". Sehingga demi kesejahteraan dan "kenyamanan" bersama, tradisi kepemimpinan laki-laki itu harus dijaga bagi masyarakat yang memang selama sejarahnya memposisikan laki-laki sebagai "penguasa"; dan c) kontekstualisasi dari kajian ini bahwa komentar Rasul tidak dalam hal mendiskreditkan perempuan, tetapi dalam konteks "kekesalan" beliau atas penghinaan Kisra. Sehingga, hadits ini tidak bisa dipahami secara kaku, meski redaksinya "menghina" dan "menyumpahi".
\end{abstract}

Kata kunci : wilāyat al-mar'ah, Hadist Nabi

\section{A. PENDAHULUAN}

Pembahasan hadits atau dalil yang lain mengenai "perempuan" telah banyak dilakukan, terlebih ketika isu gender begitu mengemuka. Lebih ramai lagi manakala sebagian dari "feminis radikal" mulai mempermasalahkan teks-teks keagamaan karena dianggap sebagai penyebab "terpinggirkannya" mereka.

Dari sinilah kemudian menjadi penting "menyegarkan kembali" akan pemahaman mengenai teks-teks keagamaan yang mungkin selama ini dianggap "memasung". Hal ini penting untuk dilakukan secara proporsional dan akademis, sehingga bagi sebagian orang yang "pobhia" dengan isu-isu terkait "kekuatan" perempuan (baca, gender) mulai berani membuka eksklusifitasnya. Dan juga bagi "pejuang" perempuan tidak terlalu "kebablasan" untuk membangun kekuasaan baru -yaitu kekuasaan perempuan di atas laki-laki-.
Penulis merasakan bahwa mereka yang mengkaji tentang "perempuan" (baca, gender) ternyata tidak bisa terlepas dari "kepentingan" masing-masing. ada yang terkesan begitu "membela" kaum perempuan dengan legitimasi rekonstruksi pemahaman teks suci dan terdapat pula yang sebaliknya, juga dengan dalil teks suci. Sehingga, dalam tulisan sederhana ini akan dikaji secara "terbuka" komentar (hadits) Nabi khususnya mengenai wilāyat al-mar'ah (sering dimaknai sebagai kepemimpinan perempuan) supaya lebih membuka "kaca mata" akademik dan akhirnya kita bisa "membaca" teks-teks keagamaan dari berbagai sudut pandang yang jelas, luas dan mencerahkan. 


\section{B. PEMBAHASAN}

Hadits yang disinyalir sebagai dasar pelarangan perempuan memegang “kekuasaan” adalah (al-Bukhari, 1987:2600):

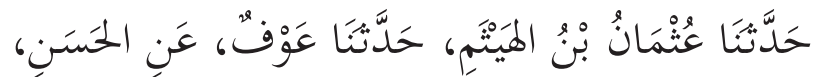

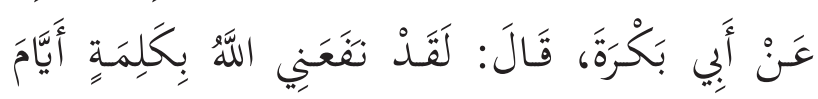

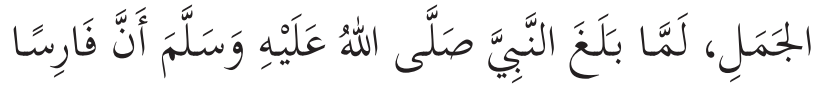

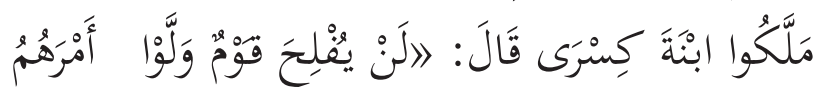

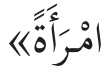

Artinya, telah menceritakan kepada kami Utsman ibn Haitsam, menceritakan kepada kami Auf, dari al-Hasan dari Abi Bakrah, ia berkata: Allah sungguh telah membantu saya dengan suatu kalimat pada waktu perang unta (waq'atu jamal), ketika disampaikan kepada Nabi saw (kabar) bahwa orang Persia menyerahkan kekuasaan pada anak perempuan Kisra, Nabi saw berkomentar: "tidak akan sukses suatu kaum apabila menyerahkan urusan mereka kepada seorang perempuan".

\section{Hadits Semakna}

Hadits-hadits yang semakna dengan hadits di atas, bertebaran dan diriwayatkan oleh beberapa imam hadits, dalam kitab alMaghāzī dengan narasi yang sedikit berbeda al-Bukhari (1987:1610) meriwayatkan:

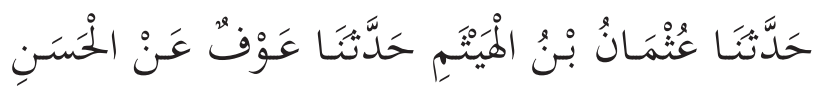

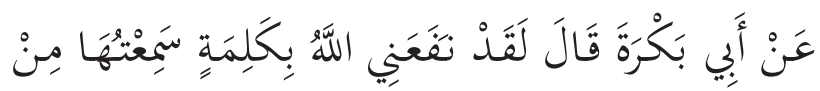

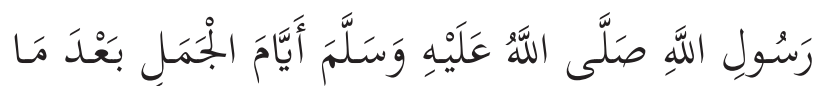

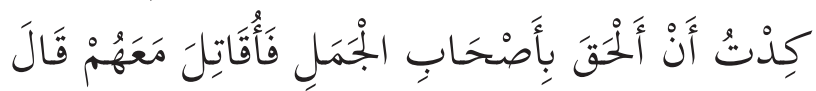

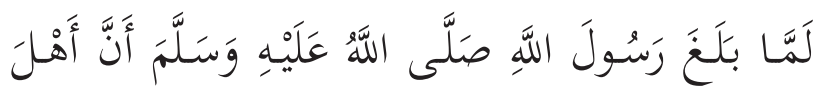

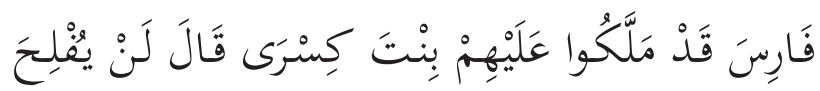

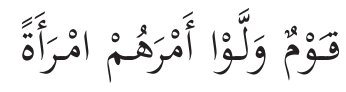

Kemudian at-Tirmidzi (t.th.:527) dengan redaksi yang lebih naratif menceritakan:

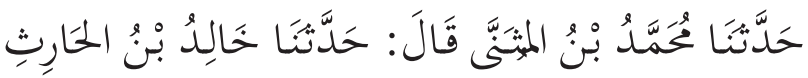

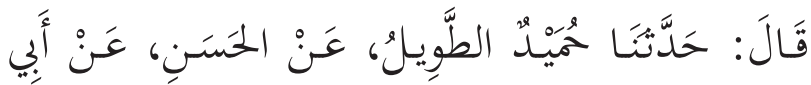

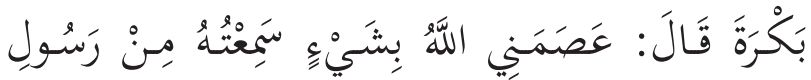

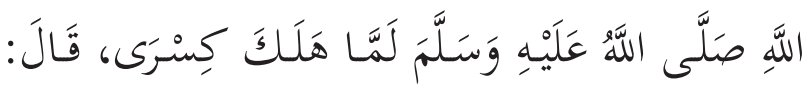

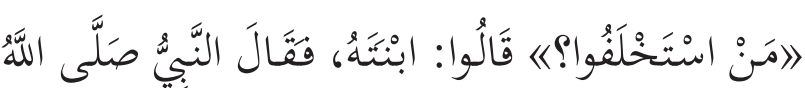

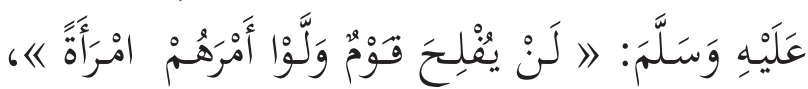

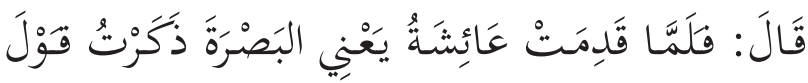

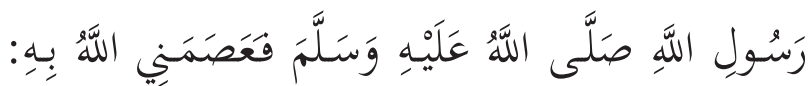

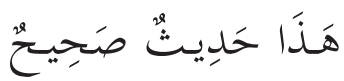

Selanjunya an-Nasa'i

(1986:227) yang hampir senada dengan at-Turmudzi meriwayatkan:

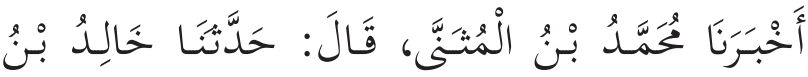

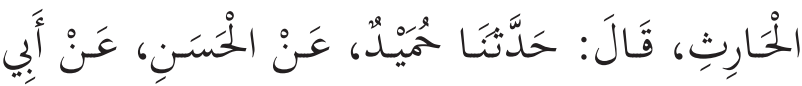

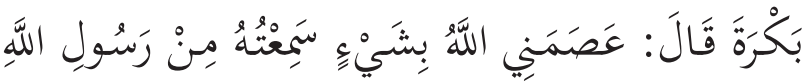

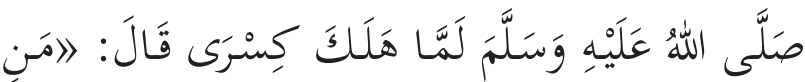

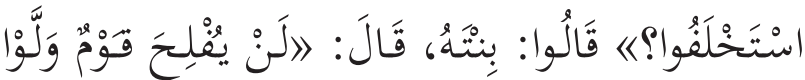

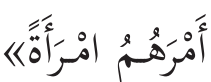

Kemudian Imam Ahmad (t.th.:38) dalam Musnadnya menceritakan:

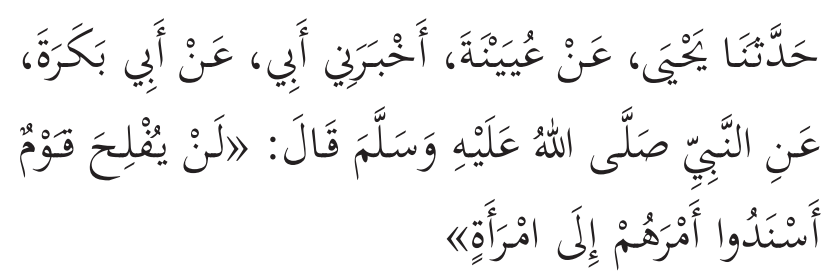

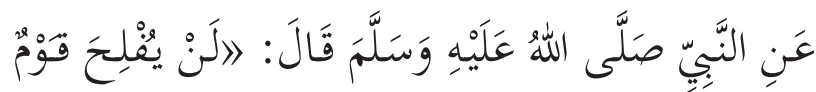

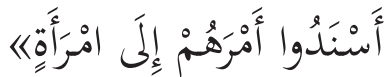


Dari beberapa versi hadits di atas, meski dengan menggunakan narasi yang hampir berbeda, tetapi pada prinsipnya sama, yaitu terkait "kekuasaan" perempuan.

\section{Analisis Bahasa}

Dalam analisis bahasa ini, terlebih dahulu kita tentukan kata-kata kunci (key therm) atau bahkan kalimat kunci yang menjadi alat pijak awal dalam melakukan analisis selanjutnya, setidaknya terdapat tiga kata kunci dalam hadits-hadits tersebut yaitu, yuflihu (berhasil), wallā (menyerahkan wilayah) atau asnada (menyandarkan urusan) dan imra'ah (perempuan). Analisis kebahasaan ini sangat penting, karena bahasa merupakan simbol dan sarana dalam penyampaian makna atau gagasan tertentu (Najwah, 2007:144). Apalagi apabila yang terdapat dalam hadits tersebut dianggap sebagai kata-kata sukar atau "aneh", maka analisis kebahasaan menjadi hal awal yang niscaya untuk dilakukan (Zuhri, 2003:5456).

Kata "yuflihu" memiliki arti keberuntungan dan kesuksesan (al-fauz wa al-najah), juga bermakna kelangengan dalam kenikmatan dan kebaikan (al-baqä' fial-na'ìmi wa al-khaīri) (Ibn Mandzur, t.th.:3458), kata tersebut disandingkan dengan huruf nashb "lan" yang sering diterjemahkan dengan "tidak" atau "tidak akan", sehingga kalimat tersebut dimaknai "tidak akan sukses atau beruntung suatu kaum yang...". Tetapi permasalahannya di sini menjadi melebar tatkala dipertanyakan katidaksuksesan atau ketidakberuntungan tersebut dalam hal apa? Dan kondisi tersebut bersifat sementara atau selamanya?. Hal ini menjadi wajar dipertanyakan karena huruf "lan" dalam kajian gramatika Arab memiliki dua fungsi makna, yaitu menyatakan selamanya (ta'bìd) -misalnya dalam Qs. Al-Baqarah (2): 130- dan menunjukkan makna tempo tertentu ( $\left.t a^{\prime} q \bar{i} t\right)$-misalnya dalam Qs. Ali Imrān (3): 92-. Dalam memaknai teks hadits ini, makna pertama lebih cocok, karena makna kedua biasanya digunakan dalam kalimat yang mengandung batasan waktu tertentu. Sehingga makna kalimatnya menjadi "tidak akan sukses atau beruntung suatu kaum (sampai kapanpun)". Kata "qaum" di sini juga disebutkan dalam bentuk "nakirah" sehingga mencakup kaum manapun dan di manapun.

Kemudian kata "wallä" memiliki arti "pemegang kekuasaan" (al-Q $\bar{a}^{\prime} i m$ bi al-wilāyah) (Ibn Mandzur, t.th.:4920). kata ini sering digunakan dalam konteks kekuasaan negara atau kekuasaan yang menyangkut wilayah publik, meski juga kadang dipakai dalam kekuasaan individu semisal kepemilikan budak atau perwalian terhadap anak perempuan (Ibn Mandzur, t.th.:4920).

Selanjutnya adalah kata "imra' $a h^{\prime \prime}$ kata ini memiliki arti perempuan, tetapi dalam istilah Arab, perempuan memiliki beberapa term, semisal "untsā" -misalnya dalam Qs. Al-Hujurāt (39): 13-, "mar'ah" -misalnya dalam Qs. Al-Tahrīm (66): 11- dan "niswah (nisā')" -misalnya dalam Qs. Al-Nisā' (4): 34- kedua term ini ada yang membedakan maknanya dan terdapat pula yang mempersamakan. Bagi yang membedakan, kata "untsā" lebih merujuk pada makna "perempuan" dengan memandang jenis kelamin, dan "niswah (nisā')" tidak hanya pada jenis kelamin, tetapi juga status dan peran. Dalam redaksi hadits tersebut kata "imra'ah" juga disebutkan dalam bentuk 
"nakirah" sehingga dapat pula berarti "perempuan mana saja".

Dengan demikian, berdasarkan pemaparan analisis kebahasaan sebagaimana di atas, hadits mengenai wilāyāt al-mar'ah ini dapat kita maknai bahwa sampai kapanpun suatu kaum (di manapun) tidak akan sukses atau beruntung apabila menyerahkan urusan (kekuasaan) mereka kepada perempuan (mana saja) untuk menjalankan peran sentral.

\section{Analisis Historis}

Analisis historis ini diarahkan pada kompilasi dan rekonstruksi sejarah (asbāb alwurūd) dan konteks ketika hadits tersebut dimunculkan dengan merujuk pada kitabkitab syarah dan sejarah (Najwah, 2007:144). Asbāb al-wurūd ini sangat penting untuk dikembangkan (apalagi dalam hadits-hadits hukum) dalam rangka untuk menguak konteks sosial budaya atau setting sosial ketika hadits itu muncul (Zuhri, 2003:6263).

Banyak pakar yang menyebutkan, bahwa kemunculan hadits mengenai "wilāyat almar'ah" ini diawali oleh peristiwa perobekan surat Rasul oleh raja Kisra. Kisahnya, jauh sebelum hadits ini muncul, Rasul pernah mengutus Abdullah Ibn Hudzaifah al-Syāmi untuk mengirimkan surat kepada penguasa Bahrain, setelah surat tersebut diterima oleh pembesar Bahrain, kemudian diserahkan kepada Kisra, setelah dibaca oleh Kisra, ia menolak dan bahkan merobek surat Nabi tersebut, kemudian setelah peristiwa perobekan surat ini sampai (informasinya) kepada Nabi, maka Nabi bersabda "siapapun yang telah merobek-robek surat saya, maka orang iktu akan dirobek-robek"(Ibn Hajar al-Asqallani, 1379H:127-128; Nizar Ali, 2008:115-116; Suryadilaga, 2007:118).

"Kekesalan" Rasul tersebut ternyata terbukti, beberapa lama kemudian kerajaan Kisra (di Persia) mengalami kekacauan yang luar biasa, terjadi banyak pembunuhan yang bahkan korban dan pelakunya merupakan orang-orang dekat bahkan keluarga kerajaan sendiri. Dan parahnya lagi, ketika terjadi suksesi kepemimpinan, justru seorang perempuan yang terpilih sebagai raja, perempuan tersebut bernama Buwaran Binti Syairawaih Ibn Kisra (cucu Kisra penyobek surat). Dan hal ini menyalahi tradisi, karena dalam sejarahnya, Persia selalu dipimpin oleh laki-laki (Ibn Hajar al-Asqallani, 1379H:127-128; Nizar Ali, 2008:115-116; Suryadilaga, 2007:118119).

Kabar mengenai hasil suksesi kepemimpinan Persia tersebut "sampai" kepada Nabi, sehingga beliau berkomentar "sampai kapanpun suatu kaum (di manapun) tidak akan sukses atau beruntung apabila menyerahkan urusan (kekuasaan) mereka kepada perempuan (mana saja) untuk menjalankan peran sentral". Komentar inilah kemudian yang dipahami oleh banyak kalangan sebagai larangan perempuan untuk menjadi "penguasa".

Apabila dikaji secara tekstual, hadits tersebut memang ada kesan "misoginis", tetapi apabila dilihat konteks munculnya komentar Nabi tersebut yang terkait dengan rentetan peristiwa "kekesalan" atas Kisra dan terpilihnya penguasa perempuan di Persia. Maka pemahaman kontekstualnya bisa kita mulai untuk paparkan. Dan inti dari tulisan ini memang 
tidak untuk menyoroti boleh atau tidaknya seorang perempuan menjadi "penguasa", tetapi lebih terfokus pada mengapa Rasul berkomentar semacam itu. Dan setelah dikaji latar belakang historisnya ternyata bisa dipahami bahwa komentar Rasul tersebut terlontar dalam dalam suasana yang masih menyimpan "kekesalan" akibat pengalaman tidak "menyenangkan" dengan Kisra di Persia (Nizar Ali, 2008:115116; Suryadilaga, 2007:119).

Penulis sebenarnya ingin mengajukan sintesa lain, yaitu bahwa hadits ini supaya tidak hanya sealakan-akan "dipaksakan" untuk "membela" kaum perempuan dan dijadikan sebagai justifikasi sahnya kekuasaan perempuan sebagaimana yang sering diungkap banyak pakar atau pengkaji terhadap hadits ini. Karena komentar Nabi secara tekstual menggunakan istilah-istilah yang umum dan terkesan menganggap "lemah" perempuan (sekali lagi secara tekstual).

KomentarNabiterhadap" perempuan" apalagi kekuasaannya, bagi penulis tidak terlepas pula dengan kondisi masyarakat yang memang "patriarkhis". Sehingga demi kesejahteraan dan "kenyamanan" bersama, tradisi kepemimpinan laki-laki itu harus dijaga bagi masyarakat yang memang selama sejarahnya memposisikan laki-laki sebagai "penguasa". Tetapi tidak menutup kemungkinan, apabila terjadi dalam komunitas atau negara tertentu perempuan justru yang menjadi " penguasa”, tetapi tidak harus dikaitkan dengan hadits diatas dan mungkin akan lebih pas apabila didasarkan pada hadits lain yang secara tekstual dan kontekstual lebih "mengapresiasi" wibawa dan kapasitas perempuan.

\section{Kontekstualisasi}

Kontekstualisasi semakna dengan melaksanakan operasional hermeneutika hadits, artinya, setelah dilakukan kajian terhadap aspek bahasa, pemahaman terhadap konteks historis, pengintegrasian dengan data lain dan menemukan ideal moralnya, maka harus ada upaya untuk mengaitkan hadits tersebut dengan era kekinian (Najwah, 2007:151).

Hadits yang dibahas dalam tulisan ini, bisa dipahami dari berbagai perspektif, terlepas dari banyaknya perdebatan yang muncul. Dan memang, haditshadits atau dalil lain yang terkait dengan perempuan pada era Nabi selalu menjadi bahan kajian yang lumayan kontroversial. Meskipun kesimpulannya, bahwa setelah Islam datanglah, posisi perempuan lebih "terangkat" dibanding era-era sebelumnya atau bahkan setelah era kenabian. Fatima Mernissi mengatakan bahwa berdasarkan beberapa fakta sejarah, kaum perempuan pada era awal Islam atau masa Rasulullah merasakan kemerdekaan yang belum pernah dirasakan sebelumnya. Baru setelah wilayah Islam meluas dan bersentuhan dengan budaya lain, khususnya paham asketisme Kristen dan misoginisme Yahudi, maka kedudukan dan kemerdekaan perempuan mengalami kemunduran (Mernissi, 1987:xii-xiii).

Pemahamn terhadap teks mengenai perempuan juga tidak bisa dilepaskan begitu saja dari keberadaan produk pemahaman lama yang selama ini dijadikan pedoman oleh para pengkaji teks. Karena dalam faktanya, para penafsir terdahulu juga menuliskan komentar-komentar yang hampir sama, yaitu seakan-akan 
"menomorduakan" perempuan dengan berbagai alasan dan analisa. Bahkan syaikhul mufassir, al-Tabarī menyatakan tentang jatuhnya Adam dan Hawa ke bumi misalnya, dengan mengutip pandangan Wahb Bin Munabbih, bahwa mereka terusir dari surga akibat kesalahan Hawa, ceritanya bahwa ketika itu Allah bertanya kepada Adam tentang pelanggaran yang dilakukan, dan Adam menjawab bahwa semua itu gara-gara Hawa, sehingga akhirnya dari peristiwa itu Tuhan menghukum Hawa dengan tiga macam hukuman, pertama, membuatnya berdarah (haid) setiap bulan, kedua, menjadikannya sebagai makhluk yang bodoh (safihah), dan ketiga, hamil dan melahirkan bayi dengan susah payah. Dalam kasus tersebut, terdapat salah seorang perawi hadits (Ibnu Yazid) yang berkomentar bahwa seandainya tidak karena Hawa, maka kaum perempuan tidak akan haid, cerdas dan melahirkan dengan mudah (Ibn Jarir al-Tabhari, 2005:310).

Kemudian dalam hal kepemimpinan, al-Zamakhsyari (1977:532-534) -yang mu'tazilah sekalipun- memberikan argumentasi mengenai mengapa lakilaki dianggap lebih "super" daripada perempuan adalah karena laki-laki memiliki kelebihan penalaran (al-'aql), tekad yang kuat (al-hazm), keteguhan (al-'azm), kekuatan fisik (al-quwwah), kemampuan menulis (al-kitābah), keahlian skill yang lain yang direpresentasikan dengan contoh menunggang kuda dan memanah (alfurūsiyyah wa al-ramy).

Dari pemaparan contoh penafsiran atau pemahaman terhadap teks di atas, kita hanya bisa mengatakan bahwa bagi mereka yang terpengaruh dengan keberadaan penafsiran teks tersebut tidaklah salah apabila mereka memposisikan perempuan pada posisi "subordinat". Dan tentunya, pemahaman tersebut ternyata berbeda dengan pandangan para penafsir atau pemikir kontemporer semisal Asghar Ali Engineer (1994:61-63), yang berpandangan bahwa keunggulan laki-laki atas perempuan bukanlah merupakan keunggulan jenis kelamin, melainkan keunggulan fungsional (masalah nafkah).

Begitu juga dengan pandangan Amina Wadud Muhsin (1994:93-94) yang sebenarnya secara eksplisit dia mengakui kepemimpinan laki-laki atas perempuan, akan tetapi harus disertai dua syarat, yaitu pertama, laki-laki harus sanggup membuktikan kelebihannya. Dan kedua, laki-laki harus mendukung perempuan dengan harta bendanya. Sehingga di sini terjadi hubungan timbal balik antara hak istimewa yang diterima laki-laki dan tanggung jawab yang dipikulnya. Apabila kedua syarat tersebut tidak terpenuhi maka laki-laki bukanlah pemimpin bagi perempuan.

Terkait dengan kontekstualisasi hadits yang dibahas dalam tulisan ini, tinggal dari perspektif mana kita memahami, apabila hadits ini dipahami sebagai hadits yang mengindikasikan adanya "pelarangan" atau minimal "ketidakbaikan" terhadap kepemimpinan perempuan, ternyata hadits ini terkait atau dilatarbelakangi oleh "ketidakpantasan" perempuan menjadi "penguasa" waktu itu, karena dianggap menyalahi tradisi. Sehingga, apabila illat atau alasan yang menyebabkan "ketidakpantasan" perempuan itu hilang, maka perempuan tetap representatif untuk 
"berkuasa" tergantung di mana perempuan tersebut berada, bagaimana tradisinya, dan menimbulkan maslahah atau bahkan sebaliknya. Tapi jangan pula memaksakan hadits ini untuk dijadikan sebagai legitimasi kekuasaan perempuan di atas laki-laki. Artinya, apabila tradisi yang terjadi adalah "penguasa" laki-laki dan itu yang paling maslahah dan paling berwibawa, maka lakilakilah yang menjadi "penguasa".

Kemudian, apabila hadits ini dipandang hanya sebagai komentar Rasul terhadap "wilāyat al-mar'ah" terkait dengan kerajaan Persia, maka ternyata "kekesalan" (kalau tidak menyebut dendam) Rasul terhadap pengalaman buruk beliau dengan Kisra berakibat pada komentar "sinis". Dan komentar ini menggunakan kalimat yang justru mengandung unsur semacam "doa" dan "ancaman" ketidakberhasilan suatu kaum yang menguasakan urusannya kepada perempuan, dan bahkan menggunakan kalimat yang umum dan mencakup siapa saja dan sampai kapanpun. Artinya, apabila Rasul saja (yang dibimbing oleh Tuhan) dalam kondisi tertentu bisa mengeluarkan komentar yang bernada "sinis", apalagi kita. Hal ini mungkin bisa kita pahami bahwa dalam kondisi yang "emosional" (apalagi terkait politik kekuasaan) boleh jadi kita mengungkapkan hal-hal yang bernada menyindir, mengancam atau bahkan menyumpahi kepada siapa saja dan menggunakan kalimat yang bagaimana saja (dalam hadits tersebut menggunakan alat "perempuan" yang ketika itu merupakan representasi dari makhluk yang lemah).

Tetapi dalam memaknai hadits tersebut, penulis lebih sepakat bahwa komentar Rasul tidak dalam hal mendiskreditkan perempuan, tetapi dalam konteks "kekesalan" beliau atas penghinaan Kisra. Sehingga, hadits ini tidak bisa dipahami secara kaku, meski redaksinya "menghina" dan "menyumpahi".

\section{SIMPULAN}

Pada prinsipnya, bahwa Islam yang tentunya tertuang dalam al-Qur'an dan hadits secara universal memiliki spirit keadilan, keseimbangan dan kesetaraan. Akan tetapi tafsir atas teks-teks keagamaan meniscayakan adanya kontekstualisasi. Penulis berkesimpulan, bahwa hadits yang dibahas dalam tulisan ini, yang sering dipahamisebagian orangsebagai pelarangan bagi perempuan untuk memegang kekuasaan, atau bahkan dipahami sebaliknya, yaitu bahwa hadits ini tidak bermakna pelarangan karena munculnya hadits ini terkait dengan dengan kekacauan di Persia yang kebetulan waktu itu suksesi kepemimpinannya mendudukkan seorang perempuan cucu Kisra sebagai "penguasa". Penulis berpandangan bahwa hadits ini dapat dipahami dari berbagai dimensi. Dari dimensi kepemimpinan politik, hadits ini mengandung makna yang lentur, artinya penguasa itu boleh laki-laki boleh juga perempuan tergantung kapasitas dan acceptabilitas penguasa tersebut di tengahtengah masyarakat yang dipimpinnya.

Kemudian dari dimensi "komentar" Nabi, seakan-akan menjelaskan bahwa karena "kekesalan" beliau (yang terpendam agaklama)terhadapKisrayangtelahmerobek surat yang telah dikirimnya, mendorong beliau "berkomentar" dengan nada yang terasa "mangkel" dan "menyumpahi". Hal ini mungkin bisa kita pahami bahwa dalam kondisi yang "emosional" (apalagi 
terkait politik kekuasaan) boleh jadi kita mengungkapkan hal-hal yang bernada menyindir, mengancam atau bahkan menyumpahi kepada siapa saja dan menggunakan kalimat yang bagaimana saja (dalam hadits tersebut menggunakan alat "perempuan" yang ketika itu merupakan representasi dari makhluk yang lemah).

Kepemimpinan perempuan itu telah menjadi realitas politik, dan bahkan dalam Islam, hal ini telah berlangsung lama. Tinggal bagaimana kita mengambil sikap terhadap teks-teks keagamaan yang selama ini kita pedomani. Apakah menyalahkan dan mengganti teks-teks keagamaan -atau sekedar mempertanyakan keabsahannya-? ataukah membuat tafsir baru yang lebih kontekstual? atau bahkan membiarkan "pertempuran" antar dua jenis kelamin yang berbeda ini semakin memuncak dan semakin mengumbar "syahwat" kepentingan masing-masing sehingga tidak mencapaipuncakpenetrasiyang sempurna?. Di sinilah arti penting rekonstrusksi dan kontekstualisasi pemahaman teks-teks keagamaan. Wallahu A'lam.

\section{DAFTAR PUSTAKA}

Ahmad Ibn Hanbal, Musnad Ahmad Ibn Hanbal, (Mesir: Mu'assasah Qurthūbah, t.th)

Al-Asqallani, Ibn Hajar, Fath al-Bari, (Beirut: Dar al-Ma'rifah, 1379 H.)

Al-Bukhari, Abu Abdillah Muhammad Ibn Isma'il, șaḥih al-Bukhārī, (Beirut: Dār Ibn Katsīr, 1987)

Al-Thabari, Ibn Jarir, Jami' al-Bayan 'an Ta'wil Ayat al-Qur'an, (Beirut: Daar al-Fikr, 2005)

Nasaruddin Umar, Argumen Kesetaraan Gender Perspektif Al-Qur'an, (Jakarta: Paramadina, 2001)

Al-Tirmidzi, Muhammad Ibn Isa, Sunan alTirmidzì, (Beirut: Dār Iḥyā' al-Turāts, t.th.)

An-Nasa'i, Ahmad Ibn Syu'aib Abu Abdurrahman, Sunan al-Nasā'í, (Aleppo: Maktab al-Matbū'āt alIslāmiyyah, 1986)

Az-Zamakhsyari, Abu al-Qasim Jār Allah, al-Kasysyaf 'an Haqa'iq al-Tanzil wa Uyun al-Aqawil fi Wujuh al-Ta'wil, Jilid I, (Beirut: Daar al-Fikr, 1977)

Engineer, Asghar Ali, Hak-hak Perempuan Dalam Islam, terj. Farid Wajdi dan Farkha Assegaf, (Yogyakarta: LSPPA Yayasan Prakarsa, 1994)

Fatima mernissi, Beyond The Feil: MaleFemale Dynamics in Modern Muslim Society, (Indiana: Indiana University Press, 1987)

Ibn Mandzur, Lisān al-Arab, (Kaero: Dar alMa'arif, t.th.), hlm. 3458.

M. Alfatih Suryadilaga, "Model-model Living Hadis" dalam Dosen Tafsir Hadits Fakultas Ushuluddin 
UIN Sunan Kalijaga Yogyakarta, Metodologi Penelitian Living Qur'an dan Hadis, (Yogyakarta: Teras, 2007)

Muh. Zuhri, Telaah Matan Hadis, Sebuah Tawaran Metodologis, (Yogyakarta: Lesfi, 2003)

Muhsin, Amina Wadud, Wanita Dalam al-Qur'an, terj. Yaziar Radianti, (Bandung: Pustaka, 1994)

Nizar Ali, Hadits Versus Sains, Memahami Hadits-hadits Musykil, (Yogyakarta: Teras, 2008)

Nurun Najwah, “Tawaran Metode dalam Studi Living Sunnah" dalam Dosen Tafsir Hadits Fakultas Ushuluddin UIN Sunan Kalijaga Yogyakarta, Metodologi Penelitian Living Qur'an dan Hadis, (Yogyakarta: Teras, 2007) 